\title{
Features of Forming of a Manpower in Strategically Important Cities of the Far East of Russia (On the Example of Vladivostok)
}

\author{
Victor Alekseevich Osipov \\ Elena Viktorovna Krasova
}

Vladivostok state university of economy and service. 690014, Russia, Vladivostok, Gogol St., 41, 1506

Email:viktor.osipov@vvsu.ru, elena_krasova@rambler.ru

\author{
Doi:10.5901/mjss.2015.v6n5s3p108
}

\begin{abstract}
This article is devoted to features of forming a workforce in territories of social and economic development, strategically important for Russia. As an example of such territory, the port city of Vladivostok located in the south of the Far East Russia on the bank of the Sea of Japan was chosen. For Vladivostok forming of a workforce is the important problem leaving the mark on dynamics of economic development and nature of the social processes proceeding in the city. In article factors of forming a human capital and a workforce of the port of Vladivostok on an extent of all history of existence of the city are considered, historical stages of this process are allocated, the reasons and features of forming a workforce of the city at each stage are designated. In addition, authors analyze a current state of a staff of Vladivostok, namely: analyze dynamics of the demographic indicators, which are a part of a labor, their gender and age structure, and their forecast until 2020. At the end of article authors give the key findings of research, main from which reflects, on the one hand, transition, long-awaited for Russia, from negative demographic tendencies to positive (growth of population size), on the contrary, negative dynamics of able-bodied population because of regressive age structure of the population. Nevertheless, authors connect the future development of labor capacity of the city with the innovation strategy based on the implementation of large regional projects.
\end{abstract}

Keywords: manpower, human potential, Far East Russia, economy of Russia.

\section{Introduction}

Vladivostok - the city and the port in the south of the Far East Russia located on the bank of the Sea of Japan about 650 kilometers from the closest coast of the Japanese island of Hokkaido. Vladivostok, along with Khabarovsk, is the largest city in the Far East region, an administrative center of Primorye Territory of Russia and the center of the biggest city agglomeration in the Far East.

Vladivostok plays a large role in political and economic life of the country. It is a terminal point of the TransSiberian long distance railway, the main transit point on the way from Asia to Europe and vice versa. In addition, Vladivostok is the primary base of the Pacific Fleet of Russia and the largest scientific and educational center of the Far East region including a number of large educational institutions of departments of the Russian Academy of Sciences.

Vladivostok was founded in 1860 and 155 years of the history repeatedly changed scenarios of the development. It happened because of change of the external and internal factors connected with the economic policy of Russia in the Far East, the international situation and other conditions. Since the second half of the XIX century, Vladivostok was both a pioneer outpost, and the city of the free zone, both military fortress, and a confidential military facility, and the capital of the Russian suburb, both the far province, and the center of international cooperation in ATR (Abramov, 2010, page 117). Vladivostok "tried on all these roles on itself" in different combinations, but one was invariable: forward forming and intensive development of human and labor capacity of the city as most important factor of the social, economic, and military-political development.

\section{Literature Review}

The world community already created a certain theoretical base of researches in the field of forming of a human capital and market development of work, considerable experience of regulation of these processes is saved up. To comprehensive consideration and the analysis, the system of forming of a manpower of the USA is exposed, to Germany, Italy, France, Australia and some other countries from the traditionally high migratory component. Russia was among the 
countries feeling the need for creation of a full-fledged management system of human capital with the high level of a migratory component not so long ago. Nevertheless, the number of the Soviet and Russian scientists - E.P. Pletnev, L.L. Ribakovsky, V.A. Iontsev, V.G. Gelbras, A.N. Kamensky, Zh.A. Zayonchovskaya, S.V. Soboleva, V.L. Larin, V.I. Dyatlov, M.L. Titarenko, Bezrukov I.S. - made the significant contribution to research on fundamental demographic and migratory problems, and also the issues connected with development of a manpower and their interrelations with process of economic development of the cities and regions of Russia. Now in connection with the intensive development of resources of the Far East region the new effective policy of traffic control of the population is necessary. With respect thereto there is a need of profound studying of factors and premises of forming of resources of work and the migratory processes accompanying it (Krasova, 2012, p. 10).

The purpose of this research is studying of features of forming of a manpower in strategically important cities of the Far East of Russia (on the example of Vladivostok). The author was faced with the following tasks: to investigate factors of forming a human capital and a manpower of the port city of Vladivostok on an extent of all its history, to give a historical assessment to separate stages of labor development of the city, to characterize a current state of a manpower of Vladivostok.

Research is based on the scientific and statistical materials describing dynamics of the major indicators connected with the development of demographic and labor processes. General provisions of economic science, works of domestic and foreign scientists in the field of researches of interregional and international migratory processes make the theoretical and methodological base of research. In the course of research, methods of logical, comparative analyzes were used. Also, the author actively used legislative, regulating, program documents of federal and regional levels.

\section{Factors of Forming a Human Capital and Manpower of the Port City of Vladivostok}

The human capital in a broad sense represents a productive factor of social and economic, cultural and moral and intellectual and innovation development of society and its certain members. Features and tendencies of development of a human capital of this or that country (the territory, the district, the city, the area, etc.) are considered through system of the factors and indicators characterizing the level of demographic and social and economic development.

The history of settling of Vladivostok, development of its human capital reflects all social and economic and military-political processes happening in the city on an extent of the entire period of active development of strategically important, but very remote and sparsely populated Far East region of Russia. In comparison with the majority of the cities in the central part of Russia having centuries-old history, Vladivostok has a number of the essential differences connected, first, with its remoteness, secondly, with his relative youth, thirdly, with intensity of its development. All this left a mark on dynamics and nature of forming of demographic, labor and personnel capacities of the city.

Considering a human capital of Vladivostok in a historical and economic and demographic context, it is possible to allocate the following factors of its development:

- strengthening of military-political presence;

- development of the territory and economic growth;

- improvement of the quality of life.

\subsection{Strengthening of military-political presence}

Vladivostok was founded as a military post on the instructions of the imperial government to provide a military presence in the Pacific Ocean. Transfer of the residence of the military governor and the primary base of the Siberian military flotilla to Vladivostok in 1871 formed the basis for a further development of the city and need of its fastest settling. Far East territories appeared open for settling by the peasants who do not have the earth, and enterprising people of all estates. For the first immigrants, the state allocated some privileges and subsidies. In particular, moved at own expense were exempted from a conscription duty during 10 sets, were exempted from a subpar tax and payment of a land tax within 20 years. In 1879 in Vladivostok 8,8 thousand people were, military settlers with families, merchants, workers and employees made the others of them $36 \%$, - the civilian population of East origin (http://old.pgpb.ru).

Occupying Vladivostok, the Russian government pursued not only especially military but also political goals. The main foreign policy task was the creation of the Russian settlements in response to the growing demographic pressure from China. Removal of social tension because of dispossession of the land of peasants became an important internal political task. For the solution of these tasks at the beginning of the XX century, P. A. Stolypin's program about resettlement to the Far East of landless peasants from internal provinces of Russia was accepted. This program, which is completely financed by the state, together with construction of commercial port and Ussuriisk railroad, provoked the rapid 
economic growth of Vladivostok, created the base of economic and human capacities of the city. In 1897 in Vladivostok lived 29 thousand people, in 1907 - nearly 87 thousand people, in 1926 - 99 thousand persons. In 1917. By the end of the first (pre-Soviet) stage of settling of the city, a manpower of Vladivostok included representatives practically of all professions, levels and classes: from longshore labors and the Chinese water carriers to large industrialists, bankers, military and government employees. Thus, the main role was assigned to military: service only of Vladivostok Fortress, which in 1915 was recognized, as the best seaside fortress of the world, the 9-thousand garrison, was engaged (http://old.pgpb.ru). Among occupations of the civilian population, the agricultural industry prevailed.

Thus, the solution of military-political tasks became the first condition for forming of the human capacity of the city, and the importance of a military-political factor over the years only increased. It is enough to take into account that Vladivostok since 1922 is base of the Pacific Fleet of Russia to this day - operational and strategic consolidation of Navy of Russia where tens of thousands of highly qualified personnel of officer and not officers serve. Moreover, China is still demographically very strong in comparison with East territories of Russia.

\subsection{Development of the territory and economic growth}

Powerful impact of development of economy on forming of human capacity of the city began in the late twenties - the beginning of the 1930th, during industrialization and militarization when the strong extracting sector and the defense industry (Motrich E.L. was created., 2006, page 121). The enterprises were created, and the problem of a deficit of manpower became the sharpest. The policy of economic development and settling of the Far East proclaimed the Soviet government within which intensive development of East territories of the country was performed, allowed to achieve impressive progress in forming of human capacity of Vladivostok. Patronage of the state and unprecedented financing of regional projects by the Soviet government promoted not only to accumulation of population size of the city, but also forming of the optimum structure of its manpower corresponding to problems of a military-political and economic development of the city and the region in general. Despite the accompanying difficulties and issues, this policy is an example of efficient use of exogenous factors for the development of human capital. Exogeneity, in this case, means the secondary, subordinated role of demographic development about the economic. In other words, human potential formed according to the set parameters of economic growth and political priorities, and not vice versa. With respect, thereto the main way of building of the population was migration, resettlements. In different years quite successful measures for attraction of working hands from the central regions of the country and to fixing of the population from which it is possible to distinguish the key were taken:

1) Use in 1930 - 1945 of work of prisoners, including political, compulsorily sent to the Far East. In 1930 for the purpose of development of natural richness of the region Management of Far East labor camps - Dallag (since 1939 there was Vladlag) was created. Prisoners of Vladlaga worked at ship repair, fisheries, logging, gold mining and coal, construction. Their hands constructed many industrial and infrastructure facilities of Vladivostok, Artemas, Ussuriisk, the Big Stone, Spasska-Dalnego and other settlements. In 1939 the number of inhabitants of Vladlaga passed for 90 thousand people, and only after 1945 - began to be reduced gradually (http://www.25.fsin.su);

2) Providing during the different periods (1930 - 1934, 1970 - 1979) the privileges to immigrants including arriving on the agricultural channel;

3) Establishment in 1946 of salary supplements to inhabitants of the southern regions of the Far East;

4) resettlement on an organized set of rendering significant financial aid in 1945 - 1953, preferential crediting of immigrants, providing privileges from the different ministries and departments;

5) The organization in 1960 of a public appeal at which in the construction organizations young men and girls according to Komsomol permits were accepted. In 1960-1961 on a call to buildings of Vladivostok there arrived about 10 thousand young workers (Vlasov S. A., 2010);

6) Introduction in the 1970th of salary supplements: percentage allowances, allowances for a continuity of an experience, coefficients for employees of the light and food industry, education and health care (Motrich E.L., 2006, page 121-125).

Except migratory measures, it should be noted such way of forming of the population of the city as natural reproduction especially. Natural reproduction has a big time log of receipt of return therefore it began to play a significant role only in the second half of the XX century. So, in the 1970-1980th when rates of a migratory gain gradually decreased because of reduction of a reserve for resettlement, natural reproduction helped to keep rather high rates of a population growth of the city.

As a result of the taken measures and active reproductive behavior of the population, the population size of 
Vladivostok grew the rates advancing growth rates of the population in general across Russia (Figure 1).

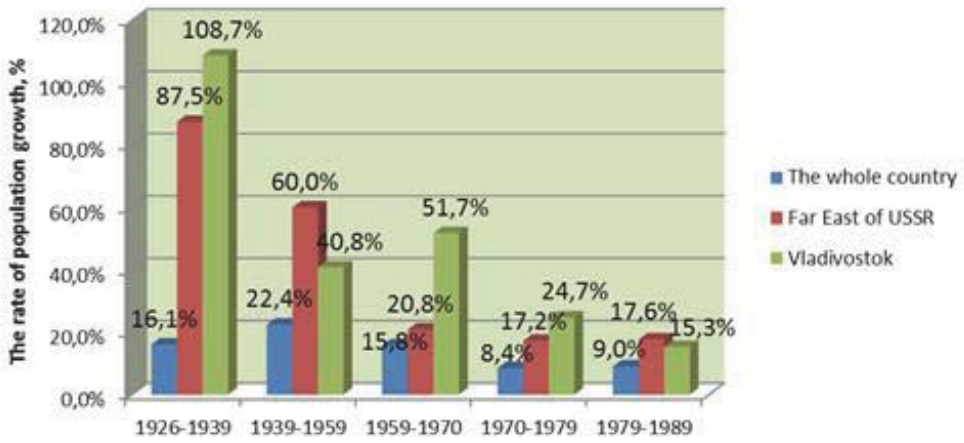

Figure 1 - Comparison of rates of a population growth of the USSR, the Far East and the city of Vladivostok for 19261989. (Population of Russia, 2008; Population of the USSR, 1990).

From 1926 for 1989 (the period between the first and last Soviet censuses) the population of the city increased by 6,4 times while the population of the Far East increased by 5 times, and the population of Russia - by 1,9 times. Being founded in 1861 at distance more than 9 thousand kilometers from the center of the country, by 1989 Vladivostok took on population size the 10th place among 33 Soviet cities with number of inhabitants from 500 to 999,9 thousand people, and on growth rates of population size - the 13th place among these cities (the Population of the USSR, 1990). Only in 128 years after the basis Vladivostok had the demographic potential comparable to the capacity of such old cities as Voronezh, Zaporozhye, Krivoy Rog, Kishinev, Izhevsk. On population size Vladivostok by 1990 exceeded the cities of Yaroslavl, Tolyatti, Ulyanovsk, Krasnodar, Frunze, Khabarovsk, Novokuznetsk, Dushanbe, Vilnius, Orenburg, Penza, Tula, Kemerovo, Ryazan, Astrakhan, Tomsk, Gomel and other cities.

In the 1990th, during the market reforms, which cardinally changed managing type in the country and the concept of development of the Far East, exogenous factors, were replaced endogenous, not assuming any reserves for building of a human capital of the city and the region in general. Unlike external factors, internal affected the population in a pushing-out way that led to the depopulation of Vladivostok, destruction of the saved-up labor potential, the emergence of cyclical unemployment and deepening of social problems. Since 1992, for the first time in all history of Vladivostok, falling of population size, reduction of labor and deterioration of their structure began. For years of falling - $1992-2009$ population size decreased by 66 thousand people, and the demographic capacity of the city returned almost on 30 years ago, to the level of the beginning of the 1980th.

\subsection{Improvement of quality of life}

For the first 130 years of the existence, Vladivostok implemented itself as naval and industrial base of Russia in the Far East. The next 20 years (the 1990-2000th) showed how brittle and unstable can be a human potential in the conditions of action of exogenous factors. In the 2000th the understanding of the strategic issues connected with the loss of human resources in the Far East, therefore, the attention of the state to the region and its key cities amplified returned. The state support was expressed in the implementation of some programs for development of the Far East, Primorye Territory and, of course, Vladivostok as the east capital of Russia.

Realities of today say that, along with the centralized measures, important, and sometimes and a priority role in the development of labor potential plays use of own, internal benefits which are available for the city. The saved-up economic power has to be converted in quality of Wednesday, in the vital long-term strategy of the people living in the city.

In the 2010th in Russia, the state policy aimed at the accelerated development of Vladivostok as the center of international cooperation in ATR was accurately issued. As showed the Soviet experiment, economic growth and considerable financial injections do not mean accumulation of human capital and growth of quality of life yet. Therefore, the federal and regional purposes of development have to be added actually with the purposes of development of Vladivostok which achievement will increase quality of life of residents to the level allowing stabilizing at first population 
size and then gradually to increase it (Abramov, 2010, page 138). Actually, it means transition from extensive strategy of forming of the population "people for economy" to the innovation concept of development of a human capital "economy for people", the attractiveness of the city assuming increase for life, work, creativity and self-realization.

The first attempts of the state since the end of the 2000th to combine grandiose plans of an economic development of the city and edge with elements of the innovation strategy for development of a human capital led to certain positive shifts in the spheres which are traditionally connected with the level of comfort of life: employment, education, including preschool, health care, housing and communal services, social policy, etc. The gradual growth of the population of the Vladivostok city district (Figure 2) became the result of it.

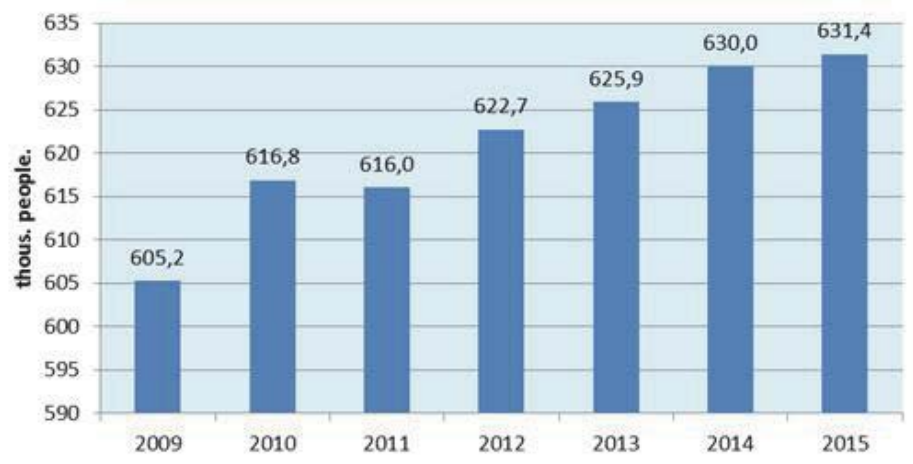

Figure 2 - Dynamics of population size of the Vladivostok city district for 2009-2015. Source: (http://www.gks.ru).

It should be noted that the positive moments have both mechanisms of growth of population size - both natural, and migratory. So, the natural movement the population of Vladivostok for the period is characterized 2009-2013 by a continuous gain of number been born and almost continuous decrease in number of the dead owing to what the tendency to reduction of natural wastage was outlined. In 2013, for the first time in 20 years (since 1993) in the city the natural increase in 67 people was recorded (Figure 3).

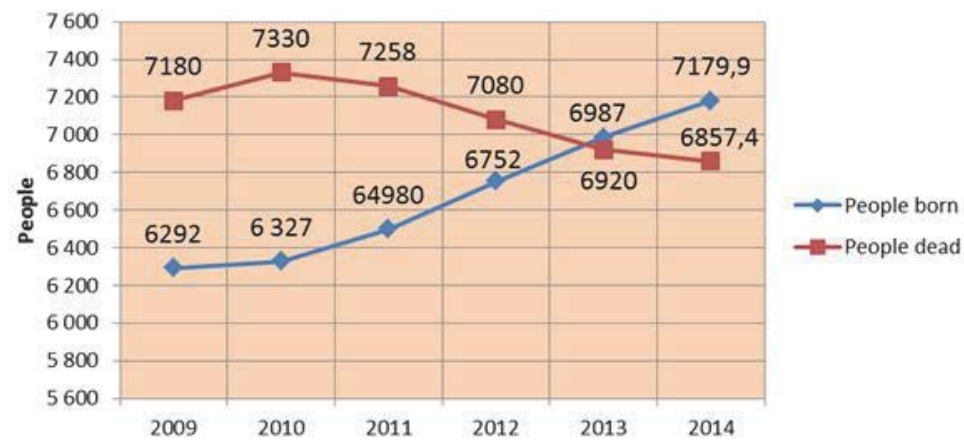

Figure 3 - Dynamics of the natural movement of the population of the Vladivostok city district for 2009-2014. (For 2014 the assessment is given).

Source: (Vladivostok - the east gate of Russia, 2014).

Important line of the natural movement of the population is gradual decrease in the mortality rate at working-age, both in absolute, and in relative indicators: in 2009 the death rate of the specified category of people made 3,788 \%, in 2012 3,136 \%, in $2013-3,119 \%$. The birth rate level increased in Vladivostok from 10,87 \% in 2009 to 11,16 \% in 2013.

The population shift in the city for 2011-2013 is also characterized by positive annual balance (Table 1). 
Table 1 - Dynamics of the migratory movement of the port city of Vladivostok for 2011-2013

\begin{tabular}{|l|c|c|c|}
\hline Indicator & $\mathbf{2 0 1 1}$ г. & $\mathbf{2 0 1 2}$ г. & $\mathbf{2 0 1 3}$ г. \\
Arrived, persons. & 26298 & 23918 & $24 \mathbf{7 2 9}$ \\
Left, persons. & 18854 & 20415 & 20637 \\
Migratory gain, persons. & 7444 & 3503 & 4092 \\
Degree of migratory activity of the population, \% & 7,33 & 7,11 & 7,24 \\
Level of migratory attractiveness of the city, \% & 16,5 & 7,9 & 9,0 \\
\hline
\end{tabular}

Source: (Vladivostok - the east gate of Russia, 2014).

Apparently from table 1, in three years on the migratory channel the population of Vladivostok increased more, than by 15 thousand persons. The main donors who are filling up the population of the city are subjects of the Far East federal district (69\% all arrived) and other regions of Russia (27\%). If to consider structure of sources of migratory growth by the accruing result for longer period - 1989-2010, it is possible to note that $52 \%$ of replenishment of the population of the city are inhabitants of Primorsky Krai, 25\% - inhabitants of other regions of the Far East and Siberia, 15\% - arrived from regions of the European part of Russia and 8\% - from the CIS countries (the Population of Russia, 2008).

A feature of the migratory movement in Vladivostok the district is a moderate degree of migratory activity of the population - on average, 7,2\% for 2011-2013. Unfortunately, the share of the population making active attempts to leave the city forever for the last 12 years decreased slightly: from 1,6\% in 2002 to $1,2 \%$ in 2013 . However, the level of migratory attractiveness calculated as the relation of a pure gain to total number migration of the active population, significantly grew: from-7,7\% in 2002 to $+9,0 \%$ in 2013 (Vladivostok - east gate of Russia, 2014).

Analyzing a city place in the general demographic system of Russia, it is possible to note that now Vladivostok is included into a 50-ka of the largest cities of Russia, taking on this list the 24th place on population size. According to the last Russian census, Vladivostok in 2010 the persons took the 11th place in 25 Russian cities with the number of inhabitants from 500 to 999,9 thousand. On the saved-up human potential Vladivostok in 2015 concedes to such cities, comparable to it, as Voronezh, Saratov, Krasnodar, Tolyatti, Barnaul, Tyumen, Izhevsk, Ulyanovsk, Irkutsk, Khabarovsk, but still exceeds Orenburg, Novokuznetsk, Tomsk, Kemerovo, Ryazan, Astrakhan, Penza, Tula, Kaliningrad, Kursk, Stavropol, Ivanovo, Belgorod, Sochi and many other Russian cities (http://www.gks.ru). The closest to Vladivostok according to characteristics of reproductive and migratory behavior the city is Khabarovsk. Reflecting, in general, the demographic tendencies inherent in all Russia, Vladivostok and Khabarovsk have the Far East specifics.

Today and shortly forming of the population of Vladivostok will go thanking both external, and internal factors that expand and supplement each other in the unity. Human development and quality of life have to be considered as primary, priority, but not a secondary factor of an evolution of the city. The prosperity of Vladivostok in the future directly depends on that, how numerous, healthy, and enterprising the aboriginal Vladivostok population will be educated. The significant and perspective instrument of implementation of the innovation strategy of development of human capital will be the project the Free port Vladivostok created using the mechanism of territories of the advancing development. The attraction of a manpower on new competitive workplaces has to be performed, mainly, due to the creation of the conditions of life activity meeting the most modern standards.

Different options of a development of the city assume various scenarios of its further demographic development. So, the inertial scenario by 2045 will increase the population by 26 thousand people, realistic - by 170 thousand persons, optimistical - by 370 thousand people. Implementation, any of scenarios, will depend on rates and quality of economic growth (A demographic annual, 2014).

\section{Dynamics and Structure of a Manpower of the Port City of Vladivostok}

The part of the population possessing the physical, spiritual and mental capacities necessary for the implementation of labor activity belongs to a manpower. These capabilities act as a basis for forming of professional skills and abilities. In a broad sense, a manpower is a potential of use of resources of work in the course of a social production in the specific territory.

The analysis of dynamics and structure of a manpower of the city includes some quantitative and qualitative indexes, such, as:

- number of able-bodied population and its share of total population size;

- gender and age structure of the able-bodied population; 
- number of a labor reserve.

1. The able-bodied population is men at the age of $16-59$ years and the woman at the age of $16-54$ years except for disabled people of I and II groups, and also the unemployed persons of working-age receiving pensions. These categories of citizens act as the base of manpower. As of 01.01.2015, the total number of able-bodied population of Vladivostok made 409,5 thousand people or $65 \%$ of total population size. On this indicator Vladivostok exceeds Russia in general where the share of able-bodied population makes only $59,3 \%$ (http://www.gks.ru), however it is impossible to forget that such situation developed due to considerable reduction of number and a share of the population of age is younger than the able-bodied. On the basis of the available age structure of the population, it is possible to predict what will be the number of able-bodied population in 5 years, without migration (table 2).

Table 2 - The number of able-bodied population of the port city of Vladivostok for 2012-2014 with the forecast for 01.01.2019.

\begin{tabular}{|l|c|c|c|c|l|}
\hline Indicator & $\mathbf{2 0 1 2}$ г. & $\mathbf{2 0 1 3}$ г. & $\mathbf{2 0 1 4}$ г. & $\mathbf{2 0 1 9}$ г. & The predicted change 2019 by 2014, \% \\
Total, thousand people & 411,8 & 410,5 & 409,5 & 393,5 & -16 one thousand persons. \\
Share in total population size, \% & 66,1 & 65,6 & 65 & 61,5 & $-3,5$ \\
\hline
\end{tabular}

Source: (Vladivostok - east gate of Russia, 2014; Demographic annual, 2014).

The adverse forecast of number of able-bodied citizens is caused by regressive age structure, at which number of elderly citizens (60 years) significantly more than a number young (till 16 years are more senior): today their ratio makes 1,6, i.e. it is the share of 1000 young people 1600 elderly. Such imbalance arose as a result of "demographic holes" of the 1990th, and as a consequence of the active irrevocable migration out of borders of Vladivostok observed in the 19902000th. Unfortunately, the developed age structure will define negative dynamics of the able-bodied population further and to strengthen the degree of social and demographic load of young residents of Vladivostok. Therefore to the city not to do without additional measures for involvement of the population from other regions.

2. The gender and age structure of able-bodied population defines quality characteristics of labor power and makes a direct impact on labor supply. The structure of able-bodied population on age groups is provided in figure 4.

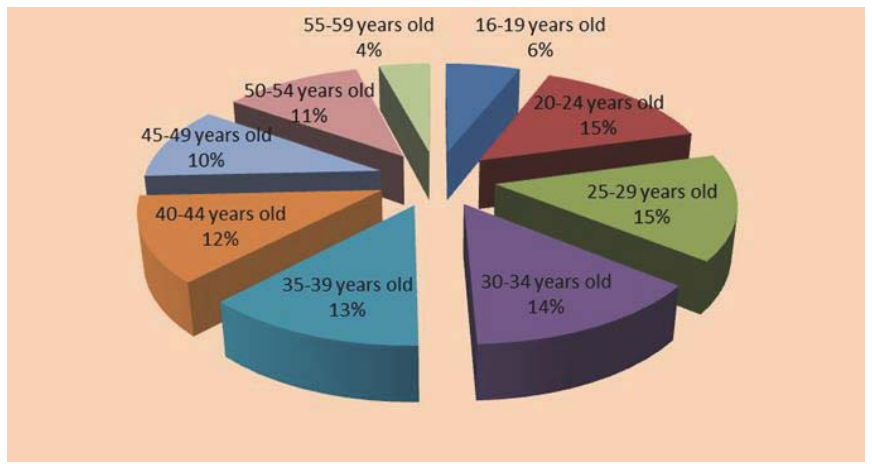

Figure 4 - The age structure of the able-bodied population of Vladivostok in 2014.

Source: (Vladivostok - east gate of Russia, 2014).

Apparently from figure 4, the greatest share $-15,1 \%$ - is occupied by citizens of Vladivostok at the age of 25-29 years: their number makes 61,5 thousand persons. On the second place there is an age group of 20-24 years from shares of $14,7 \%$ and numbering 59,9 thousand people, on the third - group of $30-34$ years from shares of $13,8 \%$ and individuals numbering 56,1 thousand. The total number of young people calculated by a technique of the International Labour Organization and including age groups till 35 years makes about 203,8 thousand persons, or $49,8 \%$ of total quantity of 
citizens, able-bodied on age. For comparison: in general across Russia the share of citizens till 35 years makes 48,3\%, i.e. it is less, than in Vladivostok. In general, it is possible to tell that the age structure of the able-bodied population of the city is rather balanced that will well be reflected in a succession of generations.

The gender structure is close to optimum, essential distortions in the number of men and women are not observed in one age group (table 3).

Table 3 - Gender structure of the able-bodied population of the port city of Vladivostok in 2014

\begin{tabular}{|c|c|c|c|c|c|}
\hline $\begin{array}{c}\text { Age group, } \\
\text { years }\end{array}$ & $\begin{array}{c}\text { Both floors, one thousand } \\
\text { persons. }\end{array}$ & $\begin{array}{c}\text { including men, one } \\
\text { thousand people. }\end{array}$ & $\begin{array}{c}\text { Share of } \\
\text { men, } \%\end{array}$ & $\begin{array}{c}\text { including women, one } \\
\text { thousand persons. }\end{array}$ & $\begin{array}{c}\text { Share of } \\
\text { women, } \%\end{array}$ \\
$16-19$ & 26,3 & 14,9 & 56,7 & 11,4 & 43,3 \\
$20-24$ & 59,9 & 30,7 & 51,3 & 29,2 & 48,7 \\
$25-29$ & 61,5 & 30,7 & 49,9 & 30,8 & 50,1 \\
$30-34$ & 56,1 & 28,1 & 50,1 & 28,0 & 49,9 \\
$35-39$ & 51,3 & 25,6 & 49,9 & 25,7 & 50,1 \\
$40-44$ & 49,5 & 25,1 & 50,7 & 24,3 & 49,1 \\
$45-49$ & 42,8 & 21,5 & 50,2 & 21,3 & 49,8 \\
$50-54$ & 45,3 & 21,6 & 17,7 & 23,7 & 5 \\
$55-60$ & 16,9 & 16,9 & 52,5 & - & -3 \\
Bcero & 409,5 & 215,1 & & 194,4 & 47,5 \\
\hline
\end{tabular}

Source: (Vladivostok - east gate of Russia, 2014; Demographic annual, 2014).

Contrary to an ordinary opinion on exceeding of the number of women and "shortage" of men, women at working-age on 20,7 thousand people it is less than men. Steady exceeding of the female population is observed only in age groupes after 50 years.

3. The labor reserve is an additional source of manpower from among those who on age does not enter the category of the able-bodied population. Usually, labor reserve consists of teenagers of 15 years wishing to work and pensioners till 72 years that did not complete the labor activity. Both categories can belong to economically active population, creating employment. In Table 4 the flowing and predicted labor reserve in the conditions of preserving of life expectancy, and also the influence of a reserve on the total number of a manpower of the city is provided.

Table 4 - A labor reserve of Vladivostok in 2014 and the forecast for 2019, one thousand persons

\begin{tabular}{|c|c|c|c|}
\hline Indicator & $2014 \mathrm{y}$. & $2019 \mathrm{y}$. & $\begin{array}{c}\text { The predicted change } \\
2019 \text { by } 2014, \%\end{array}$ \\
\hline In total reserve & 89,6 & 104,2 & +14,6 тыс. чел. \\
\hline - including at the expense of young people of 15 years & 4,4 & 4,6 & $+0,2$ \\
\hline Reserve share in population size, $\%$ & 14,2 & 16,3 & $+2,1$ \\
\hline Total number of a manpower & 499,1 & 497,7 & $-1,4$ \\
\hline
\end{tabular}

Source: (Vladivostok - east gate of Russia, 2014; http://www.gks.ru).

Apparently from table 4, now the labor reserve of Vladivostok makes 89,6 thousand persons. It means that in case of economy "overheat", i.e. at critically high growth rates, the city can expect 89,6 thousand persons of labor power also. The youth of 15 years makes only $4,4 \%$ of the available reserve; pensioners make another part. Despite the small predicted growth of a reserve for 2019 , the deep age distortion guards him: the city will not be able long to use such reserve.

The maximum number of a manpower of Vladivostok taking into account able-bodied population and manpower reserves makes 499,4 thousand people, thus, $82 \%$ of resources are occupied by able-bodied population, $17 \%$ - a reserve from among pensioners and only $1 \%$ - a reserve from among youth.

Speaking about perspective, it is possible to tell that against a decrease in the number of the able-bodied population the need for working hands will increase. According to the Federal law, on territories of the advancing social and economic development in the Russian Federation, the Far East is the region in the territory of which zones of the advancing development form (http://kremlin.ru). Till 2020, it is going to implement 30 large investment projects. The greatest number of workplaces will be created in a petrochemical cluster (5,4 thousand workplaces), in a transport and 
logistic cluster (2,4 thousand), ship repair and shipbuilding (6,5 thousand), power production (3,5 thousand), in a tourist complex (to 30 thousand). Implementation of investment projects will allow to create about 74 thousand new workplaces that in turn will entail still significant shortage of manpower. However, it belongs already to a subject of other research.

\section{Conclusions on Research}

Summing up those above, it is possible to draw the following findings concerning factors of forming of the population of the Vladivostok City district.

1. From the second half of the XIX century and to the second half of the XX century development of demographic and labor potentials was influenced by exogenous factors, namely: strengthening of military-political power and creation of an economic complex. The population policy was secondary about economic and was based on migratory methods involvement of the population. From 1990th endogenous factors became prevailing, and since the end of the 2000th in connection with a new course of strategic development of The Far East both exogenous and endogenous factors are combined. Visually and generally information on stages of forming a human capital is provided in Table 5.

Table 5 - Factors of forming a human capital of the port city of Vladivostok

\begin{tabular}{|c|c|c|c|}
\hline Period & $\begin{array}{l}\text { Purposes and problems of development of human } \\
\text { capital }\end{array}$ & Methods of forming of the population & $\begin{array}{l}\text { The created } \\
\text { demographic potential }\end{array}$ \\
\hline $\begin{array}{l}\text { The second half of the } \\
\text { XIX century - the } \\
\text { beginning of the XX } \\
\text { century. }\end{array}$ & $\begin{array}{l}\text { Creation of military base on the Pacific Ocean, agrarian } \\
\text { resettlement, settling of boundary territories (external } \\
\text { factors) }\end{array}$ & $\begin{array}{l}\text { The centralized state policy, mass } \\
\text { resettlements from internal provinces of } \\
\text { Russia }\end{array}$ & $\begin{array}{l}\text { By } 1926 \text { y.: } \\
98,9 \text { thousand persons. }\end{array}$ \\
\hline 1926 г. - 1939 у. & $\begin{array}{l}\text { Development of the territory, creation of industrial base } \\
\text { due to transition to industrial development (external } \\
\text { factors) }\end{array}$ & $\begin{array}{l}\text { Voluntary resettlements forced relocations } \\
\text { of political prisoners. Providing privileges } \\
\text { to voluntary immigrants }\end{array}$ & $\begin{array}{l}\text { By } 1939 \text { y.: } \\
206,4 \text { thousand persons. }\end{array}$ \\
\hline 1939 у. -1959 у. & $\begin{array}{l}\text { Creation and development of the strong extracting } \\
\text { industry, the defense industry (external factors) }\end{array}$ & $\begin{array}{l}\text { Organized sets with providing privileges. } \\
\text { Introduction of salary supplements }\end{array}$ & $\begin{array}{l}\text { By } 1959 \text { y.: } \\
290,6 \text { thousand persons. }\end{array}$ \\
\hline 1959 у. - 1970 у. & $\begin{array}{l}\text { Complex development of productive forces of the city, } \\
\text { creation of an industrial and social infrastructure (external } \\
\text { factors) }\end{array}$ & $\begin{array}{l}\text { Organized sets with providing privileges, a } \\
\text { public appeal. Financing of construction of } \\
\text { houses for immigrants }\end{array}$ & $\begin{array}{l}\text { By } 1970 \text { y.: } \\
440,9 \text { thousand persons. }\end{array}$ \\
\hline 1970 y. - 1979 y. & $\begin{array}{l}\text { Complex development of productive forces of the city, } \\
\text { industrial and social infrastructure (external factors) }\end{array}$ & $\begin{array}{l}\text { Providing monetary privileges: } \\
\text { introduction of coefficients and salary } \\
\text { supplements, providing lifting means to } \\
\text { graduates, privileges for independent } \\
\text { immigrants }\end{array}$ & $\begin{array}{l}\text { By } 1979 \text { y.: } \\
549,8 \text { thousand persons. }\end{array}$ \\
\hline 1979 y. - 1990 y. & $\begin{array}{l}\text { Complex development of productive forces of the city, } \\
\text { industrial and social infrastructure, aspiration to improve } \\
\text { quality of life (external factors) }\end{array}$ & $\begin{array}{l}\text { Action of the allowances entered earlier, } \\
\text { improvement of social service }\end{array}$ & $\begin{array}{l}\text { By } 1989 \text { y.: } \\
633,8 \text { thousand persons. }\end{array}$ \\
\hline $\begin{array}{l}1991 \text { y. - the first half } \\
\text { of the 2000th. } \\
\text { The end of the 2000th } \\
\text { - the 2010th. }\end{array}$ & $\begin{array}{l}\text { The population survival in the conditions of destruction of } \\
\text { social and economic potential (internal factors) } \\
\text { Implementation of strategic investment projects on the } \\
\text { development of the extracting industries. A development } \\
\text { of the city as center of international cooperation in ATR (a } \\
\text { combination of external and internal factors) }\end{array}$ & $\begin{array}{l}\text { Orientation to business activity, self- } \\
\text { employment, "shuttle" trade with China } \\
\text { Fixing of the having population by } \\
\text { improvement of quality of life: } \\
\text { employment, providing educational, } \\
\text { medical and cultural services }\end{array}$ & $\begin{array}{l}\text { By } 2009 \text { y.: } \\
578,6 \text { thousand persons. } \\
\text { By } 2015 \text { y.: } \\
631,4 \text { thousand persons. }\end{array}$ \\
\hline
\end{tabular}

Sources: (Motrich E.L., 2006; Population of the USSR, 1990; http://www.gks.ru).

2. The current period of time (2009-2015) is characterized by transition from negative tendencies to positive, namely: growth of quantity given rise, decrease in number of the dead, positive migratory balance, increase in level of migratory attractiveness of Vladivostok and, as a result of everything listed - the potential growth of population size.

3. Future development of a human capital of the city is connected with the innovation strategy on the basis of implementation of large regional projects, including such as free port Vladivostok, territories of the advancing development and others.

4. The number of able-bodied population of Vladivostok makes 405,9 thousand people, or $65 \%$ of total population size and has negative dynamics because of the regressive age structure of the population. The able-bodied population of Vladivostok has a rather balanced internal structure on a floor and age today.

5. The general manpower of the city is estimated at 499,4 thousand people or $79 \%$ of its population. It is slightly 
better, than, in general, across Russia. For comparison: across all Russia the share of manpower makes $74 \%$. Able-bodied population does the most of resources.

\section{References}

Abramov, A.L. (2010) Possible scenarios of development of Vladivostok in the long term//Strategic planning at the interregional, regional and city levels: what will be the Far East after the crisis. Series "Scientific reports: an independent economic analysis", №. 207. M, Moscow public scientific fund. pp. 117-143.

Vladivostok - east gate of Russia: Statistical yearbook / [redkol.: V. F. Shapovalov (previous), etc.]; Federal soldier. Service state. Statistics on Primor. To edge. - Vladivostok: Primorskstat, 2014. pp. 122.

Vlasov S. A. Forming of personnel in the construction organizations of the Far East (the middle of the 1950th the 1980th)//News of the Altai state university. 2010. №. 4-2. pp 28-33.

Demographic annual of Primorsky Krai: statistical collection / [redkol.: V. F. Shapovalov (previous), etc.]; Federal soldier. Service state. Statistics, Territory. Body federal soldier. Services state. Statistics on the Comment to the edge. Vladivostok: Primorskstat, 2014. pp. 96.

Motrich, E.L., Kravchuk S.A. (2006) A state policy of economic development and settling of the Far East since the end of the XIX century to the middle of the 1980th/the DVO Russian Academy of Sciences Bulletin. No. 6. pp. 120-128.

The population of Russia 2006: Fourteenth annual demographic report / otv. edition A.G. Vishnevsky / State. un-t Higher School of Economics. M.: Prod. house of GU HSE. 2008. pp. 229.

The population of the USSR: According to All-Union Population Census of 1989 / Goskomstat of the USSR. - M.: Finance and Statistics, 1990. pp. 45.

The site of Seaside state public library of A.M. Gorky. Project "Territory: Primorsky Krai. History and the current state of Vladivostok". Access mode: http://old.pgpb.ru/cd/terra/vlad/vlad 05.htm.

Site of Federal State Statistics Service of the Russian Federation. Access mode: http://www.gks.ru/wps/wcm/connect/rosstat_main/ rosstat/ru/statistics/population.

The site of Russian Federal Penitentiary Service across Primorsky Krai. History UIS of Primorsky Krai. Access mode: http://www.25.fsin.su/structure/Histori.

The federal law "About territories of the advancing social and economic development in the Russian Federation". The State Duma accepts it on December 23, 2014, and it is approved by the Federation Council on December 25, 2014. Official site of the Kremlin. Access mode: http://kremlin .ru/acts/news/47349. 